\title{
New Dimensions of Gender and Political Leadership During COVID-19: Linking Feminist Stewardship and Electoral Success in Queensland, Australia
}

\author{
Susan Harris Rimmer, Elise Stephenson, Tom Verhelst ${ }^{1}$
}

\begin{abstract}
Scholars, such as Carol Johnson and Blair Williams, have argued that COVID-19 has led to more favorable coverage of female political leaders than was previously the case. This is attributed to a traditional perception of the motherly role associated with the political response. They laud New Zealand as an exemplary feminist political response in this crisis. Yet Queensland, an Australian state, is also headed by a female politician, with an equivalent population of just over five million, just over 1,300 COVID-19 cases, and only seven deaths. Like Jacinda Ardern, Queensland Premier Annastacia Palaszczuk won an election in October 2020, in what was perceived as a referendum on her government's approach to COVID-19 response and recovery. Instead of invoking maternal images, she instead exercised what we term "feminist stewardship" by transferring her legal power over to apolitical medical experts. She was seen to display feminine protectionism by closing internal borders and resisting pressure to re-open borders from male elites who labelled her "heartless." Even so, her party's economic recovery package remained resolutely focused on traditional male-dominated areas of mining and construction. This paper extends our understanding of gender and political leadership during COVID-19 by drawing on extensive gender disaggregated health, economic, and electoral data.
\end{abstract}

\section{Introduction}

Interest in crisis leadership has grown rapidly during COVID-19. Globally, gendered leadership styles have arisen in response to mass uncertainty and emerging health and economic priorities, from the rise of the strongman leader to feminist protector. ${ }^{1,2}$ Whilst Donald Trump and Boris Johnson provided examples of more populist-style strongman leadership traits, Carol Johnson and Blair Williams, academics from the Australian National University and University of Adelaide who have studied leadership during the pandemic, drew on the case of Jacinda Ardern in New Zealand to argue that the "COVID-19 pandemic has provided unusual opportunities for women leaders to display forms of protective femininity." 3 This article seeks to build on their argument, using the case of Queensland, Australia, to explore the concept of feminist stewardship at subnational levels. ${ }^{4}$ Like Jacinda Ardern, Queensland Premier Annastacia Palaszczuk won an election in October in what was perceived as a referendum on COVID-19 response and recovery. Yet, rather than invoking maternal images of the feminist protector, she instead exercised what we term as feminist stewardship.

According to the public administration and public service ethics literature, stewardship highlights forms of leadership that seek to serve collective goals or guard the interests of their principals, as opposed to an agency-centric view of leaders acting out of self-interest. ${ }^{5}$ Stewardship goes beyond maternal protectorship espoused by Johnson and Williams to conceptualize a leadership style more gender neutralor even masculine - in behavior and yet feminist in aims. ${ }^{6}$ This article seeks to explore and define the concept of feminist stewardship during a crisis, extending our understanding of gender and political leadership during the COVID-19 crisis by drawing on extensive gender disaggregated health, economic, and electoral data.

First the article will canvas the literature, with the aim of further refining and defining feminist stewardship. Then, using the case study of Annastacia Palaszczuk's premiership of Queensland during COVID-19 and her re-election, we will explore the concept of feminist stewardship and its outcome on

Professor Susan Harris Rimmer is the Director of the Policy Innovation Hub at Griffith University in Brisbane Australia. Dr. Elise Stephenson is a Research Fellow in the Policy Innovation Hub. Dr. Tom Verhelst is the Program Director at Griffith University's Regional Innovation Data Lab at Griffith University. 
COVID-19 health, economic, and electoral outcomes. Ultimately, we argue that while in ordinary times there are few differences between gender and leadership outcomes - with the exception of public perception of leadership which heavily favors men-in crisis, gendered leadership matters.

\section{Methodology}

To establish the link between gendered leadership and COVID-19 outcomes as a national level, we rely on the study by Garikipati and Khambhampati, using a constructed dataset for 194 countries, in which a variety of socio-demographic variables were used to match nearest neighbors. ${ }^{7}$ Their findings reveal COVID-19 outcomes are systematically better in countries led by women and conclude, "to some extent, this may be explained by the proactive and coordinated policy responses adopted by them." 8 They also find evidence that, "being risk averse with respect to loss of lives and having a clear, empathetic, and decisive communication style made a significant difference to immediate outcomes of the COVID pandemic in women-led countries." 9 Queensland, the third largest Australian state, headed by a female politician, with an equivalent population to New Zealand of over five million, experienced just over 1,300 COVID-19 cases and only seven deaths as of April 2021. ${ }^{10}$

We build upon their discussion of possible reasons why there is a gender correlation by applying the stewardship literature to an in-depth case study of Queensland, Australia, where the leadership issues were aired thoroughly in the first ever State election in Australian history contested by two women. Premier Annastacia Palaszczuk emerged from the October 2020 election as the most successful female politician in Australian history, becoming the first woman to win three elections in a row. She was also the first woman in Australia to win an election from opposition in 2015, and the first to achieve gender equity in an Australian ministry in 2017. This case study is supported with datasets based on gendered economic outcomes and political voting patterns during 2020 for the state of Queensland to give a snapshot of how gendered leadership matters.

\section{Defining Feminist Stewardship}

While feminist stewardship has not been conceptualized in the literature until this paper, complementary theories do have merit in exploring and extrapolating what feminist stewardship is and could be. Social role theory, for instance, argues that humans attribute gendered characteristics to certain roles due to the male or female domination of that field - as an example, men are more likely to be in political leadership, and therefore we are more likely to associate the characteristics of a good leader with men than with women. ${ }^{11}$ Following this logic, women have been argued to be driven more by communal goals, whereas men are viewed as pursuing more agentic goals. ${ }^{12}$ Through this lens, women's leadership styles could be characterized as being naturally aligned with conceptions of stewardship. Indeed, while the stewardship literature may not have been overly concerned with gender to date, stewardship may already be inherently feminist due to our perceptions of the roles, characteristics, and behaviors of women leaders as being more "stewardly" in the first place, especially in relation to assessment of risk.

Traditional definitions of leadership have focused on masculine notions of the hero, characterized by strength, courage, determination, and vision. Rost's 1991 study of 221 definitions of leadership concluded that leadership can be perceived as rational, hierarchical, management-oriented, quantitative, cost-driven, technocratic, male, short-term, materialistic, and pragmatic. ${ }^{13}$ Stewardship, by contrast, has centered on more communal, feminine values, such as empathy, shared norms and goals, consensusbuilding, and "pro-organizational, collectivistic behaviors"-instead of individualistic, self-serving behaviors. ${ }^{14}$ In conceptualizing feminist stewardship, we extend the definition of stewardship to include more explicit "feminine" traits: attention to social protections and welfare; a deference to expert medical advice; personal, everyday forms of communication; and more attention to gender-sensitive economic recovery policies. Yet, feminist stewardship differs from the feminist protectionism as witnessed in Johnson 
and Williams's case, in that it does not rely on mothering tropes or overt displays of feminine affection in the same ways that they argue Jacinda Ardern displayed. Palaszczuk is different.

\section{The Context: Women's Political Leadership in Queensland}

In 2009, Anna Bligh became the first woman in Australia to win an election as premier. Six years later, Annastacia Palaszczuk was the first woman to lead an opposition party into government. She also installed the first female-dominated cabinet in Australian history, with eight out of the 14 ministers being women in 2015. Queensland's last state election took place on October 31, 2020, making it one of Australia's (and the globe's) first COVID-19 elections. Voters opted to stay with the incumbent, re-electing Australian Labor Party (ALP) female premier, Annastacia Palaszczuk. Her 2020 cabinet continues to exhibit perfect gender parity, with 13 female and 13 male ministers and assistant ministers, a feat first managed by Palaszczuk in $2017 .{ }^{15}$

Palaszcuk's leadership style does not fit the model of feminist protector evoked by Johnson and Williams's characterization of the charismatic Jacinda Ardern. Palaszcuk is viewed as pragmatic, authentic, and reasonable by the Queensland electorate, marking a sharp contrast to the past leaders of Queensland, which generally had a "reputation for populist and authoritarian (and, until fairly recently, exclusively male) leaders in a polity argued to be readily accepting of domineering leadership," according to Chris Salisbury's research. ${ }^{16}$ Instead, unique to Queensland's handling of the pandemic was the substantial transfer of regulatory power to the Chief Health Officer Janette Young in March 2020 until March 2021. Under emergency amendments to the Public Health Act 2005, passed on March 19, 2020, the Chief Health Officer was granted sweeping powers to limit, or respond to, the spread of COVID-19 in Queensland. ${ }^{17}$ She can close borders, order lockdowns, direct restrictions on people's movements or contact with others, and force people to stay at - or away from — stated places. It also gives force to "any other direction the chief health officer considers necessary to protect public health." This is the most power given to a health official in any jurisdiction globally to combat the pandemic, according to our research; a key attribute of feminist stewardship is yielding power to greater expertise in a crisis.

\section{The Gendered Crisis}

COVID-19 has been well-recognized as a gendered crisis, from the exacerbation of the gendered division of unpaid labor, to concerns around rising domestic violence from lockdown measures, to the prevalence of female-dominated industries at the frontline of pandemic response and economic fallout. ${ }^{18,19,20}$ Our focus on gendered leadership during the pandemic is warranted, not only because of general correlation to health outcomes, but also because of the gendered impacts of the pandemic thus far. Evidence shows that women have been - and continue to be - disproportionately affected by the economic and social consequences of the COVID-19 outbreak, though slightly less likely to contract the virus. The combination of economic and social pressures as well as limitations on movement have been termed a "shadow pandemic" and a "perfect storm" for increasing women's vulnerability to family violence and femicide. At most risk are women who face multiple forms of oppression, such as older women, rural and remote women, women with disabilities, indigenous women, migrant women, and victims of trafficking. ${ }^{21}$

The intersectional challenges faced by women extend beyond violence to economic empowerment, education, and political participation. According to International Labour Organization data from 55 highand middle-income countries, 29.4 million women aged 25 and older lost their jobs between Q4 2019 and Q2 2020. Slightly fewer men lost theirs (29.2 million), but since far fewer women were in the workforce, women's proportional loss is higher. ${ }^{22}$ To add to this, the World Health Organization states that women make up the bulk of essential care-sector workers, including 70 percent of health-care workers. Despite their importance, countries have poorly prioritized investments in care sectors, leading to shortages of health workers and poor working conditions. ${ }^{23}$

Additionally, there were 86,000 fewer women studying at Australian universities in 2020 compared with 2019, following the gendered impact of COVID-19 and the recession on Australia. Newly released 
data from the Australian Bureau of Statistics has shown that there was a 7 percent drop in the number of women enrolled at universities and some vocational courses, versus a 2 percent drop in the number of men. ${ }^{24}$ Further, in Prime Minister Scott Morrison's National COVID-19 Coordination Commission, only two out of eight appointed commissioners were women, with ethnic and sexual diversity nowhere to be seen. This imbalance has not gone unnoticed, particularly with Australian Public Service Commission requiring that boards across government, for instance, must maintain a fifty-fifty gender balance.

Queensland was largely spared from the worst economic effects of the COVID-19 pandemic, but the economic impacts were gendered. According to data from the Australian Bureau of Statistics, the March 2020 lockdown led to a reduction in the labor force participation rate by 3 percent for women and 2.5 percent for men from March to April 2020. Comparing January 2020 to January 2021 reveals that there are gendered differences in the road to economic recovery. The labor force participation rate for men has rebounded by 0.7 percent while the participation rate for woman has only increased 0.2 percent. The pandemic is widening the participation gap between woman and men from 8.3 percent in January 2020 to 8.8 percent in January 2021 (noting the labor force participation rate of 70.1 per cent for Queensland men in January 2020 versus 61.9 percent for Queensland women in January 2020, and a participation rate of 70.8 percent for Queensland men in January 2021 versus 62.1 percent for Queensland women in January 2021). ${ }^{25}$

Queensland unemployment rates experienced similar increases because of the state-imposed March 2020 lockdown. The female unemployment rate increased from 5.5 percent in January 2020 to reach its peak in July 2020 at 8.4 percent, falling to 6.4 percent in January 2021 . The unemployment rate for Queensland males is higher overall, but follows a similar pattern to that of females. The male unemployment rate increased from 6.8 percent in January 2020 to peak in July 2020 at 9.2 per cent to falling to 7.5 percent in January $2021 .^{26}$

Additionally, Australia has two types of welfare payments designed to stabilize the economic impact of COVID-19 pandemic, JobKeeper and JobSeeker. JobSeeker is a payment made to an individual who is currently unemployed but searching for employment. The JobSeeker Coronavirus Supplement was reduced from AU $\$ 550$ per fortnight to $\$ 250$ per fortnight in January 2021 and will be further reduced to $\$ 150$ beginning March 31, 2021. JobKeeper, meanwhile, is a payment made to an organization with employees that meet certain criteria and have had their turnover impacted by the COVID-19 pandemic. The JobKeeper Coronavirus Supplement started on March 30, 2020 at a maximum of AU\$1,500 per fortnight and was reduced to $\$ 1,000$ per fortnight since January 2021.

The number of Queensland woman receiving JobSeeker payments increased from 86,277 in the first quarter of 2020 to 149,072 in the second, receding slightly to 140,243 in the third quarter of 2020 . In the first three quarters of 2020, 54 percent of the JobSeeker payments went to men and 46 percent to woman.

Table 1: Covid-19 Social Security Employment Payment Data, 2020

\begin{tabular}{|l|l|l|l|l|l|l|}
\hline \multicolumn{7}{|l|}{ Queensland } \\
\hline & Male & Female & Total & Male & Female & Total \\
\hline Q3 2020 & 167,650 & 140,243 & 307,893 & 751,237 & 648,621 & $1,399,858$ \\
\hline Q2 2020 & 178,429 & 149,072 & 327,501 & 773,379 & 667,908 & $1,441,287$ \\
\hline Q1 2020 & 97,436 & 86,227 & 183,663 & 408,135 & 384,679 & 792,814 \\
\hline
\end{tabular}

Source: data.gov. $\mathrm{au}^{27}$

Despite Australia's private sector employing more men (55.1 percent) than women (44.9 percent), more women were impacted by the sector's decline between February 2020 and May 2020. Females accounted for 54.3 percent of the decline in private sector employment, while males accounted for 45.7 percent. JobKeeper applications providing organizations with funds to continue employment were provided in higher numbers to men ( 52.9 percent) than to women $(47.1$ percent $){ }^{28}$ This can be partly explained by the higher number of men in private sector employment and the exclusion to 
JobKeeper of some sectors like the University sector where staff is more likely female (57 percent in case of Universities, according to Larkins). ${ }^{29}$

In Australia between March 14, 2020 and October 3, 2020, job losses for males (5.0 percent) were slightly higher than job losses for females ( 4.2 percent). Women fared better than men in terms of wage losses during the same period. Men saw their wages decrease by 5.6 percent compared to 0.4 percent for women. This phenomenon may be explained by the higher number of men in full-time employment than women. Additionally, the lower rate of wage loss for women can be attributed to women having lost jobs that are lower-paid compared to those of men. ${ }^{30}$

Table 2: Gendered Impact on Wages during Covid-19

\begin{tabular}{|l|l|l|l|l|}
\hline & \multicolumn{2}{|c|}{ Change in Payroll Jobs } & \multicolumn{2}{c|}{ Change in Total Wages } \\
\hline & 19 Sep to 3 Oct & 14 Mar to 3 Oct & 19 Sep to 3 Oct & 14 Mar to 3 Oct \\
\hline Males & -1.1 percent & -5.0 percent & -2.3 percent & -5.6 percent \\
\hline Females & -0.9 percent & -4.2 percent & -2.3 percent & -0.4 percent \\
\hline All persons & -0.9 percent & -4.1 percent & -2.2 percent & -3.3 percent \\
\hline
\end{tabular}

Source: Parliament of Australia ${ }^{31}$

\section{Voting Patterns}

While the impact of the pandemic in Queensland was gendered, and feminist perspectives did not explicitly dominate the campaign nor Palaszczuk's leadership style, women were crucial when it came to the result of the 2020 election. The progressive Australian Labor Party (ALP) won the last state election because of its lead amongst woman voters. On all party preferred basis, women favored the ALP 38.5 percent over the conservative Liberal National Party (LNP) 34 percent, while men favored the LNP 36.5 percent over ALP 32.5 percent, 10.5 percent of women voted for the progressive Greens party, versus 9.5 percent of men, and fewer women voted in favor of the extreme right party, One Nation, compared to men (Table 3).

Table 3: Voting Preference by Gender

\begin{tabular}{|c|c|c|c|c|c|c|}
\hline \multicolumn{3}{|c|}{ Queensland Electors 18+ } & \multicolumn{2}{|l|}{ Gender } & \multicolumn{2}{|l|}{ Region } \\
\hline PRIMARY & $\begin{array}{l}2017 \text { Qld } \\
\text { Election }\end{array}$ & $\begin{array}{l}\text { Oct 12-15, } \\
2020\end{array}$ & Men & Women & Brisbane & $\begin{array}{l}\text { Country } \\
\text { Areas }\end{array}$ \\
\hline VOTE & percent & percent & percent & percent & percent & percent \\
\hline ALP & 35.4 & 36 & 32.5 & 38.5 & 36.5 & 35 \\
\hline LNP & 33.7 & 35 & 36.5 & 34 & 37 & 33 \\
\hline KAP & 2.3 & 2.5 & 2.5 & 2 & 1.5 & 3.5 \\
\hline One Nation & 13.7 & 12 & 13.5 & 10.5 & 10.5 & 13.5 \\
\hline Greens & 10 & 10 & 9.5 & 10.5 & 9.5 & 10.5 \\
\hline Independents/Others & 4.9 & 4.5 & 5.5 & 4.5 & 5 & 4.5 \\
\hline TOTAL & 100 & 100 & 100 & 100 & 100 & 100 \\
\hline
\end{tabular}

Source: Roy Morgan ${ }^{32}$

One of the driving policy questions in the 2020 Queensland election related to maintaining a border closure with neighboring state, New South Wales. At the time of the election, the state was experiencing an active COVID-19 outbreak. The Australian Labor Party (ALP) was the strongest supporter of maintaining border closures with neighboring states. Women favored keeping the border closed by 57 percent versus 49 percent of men, suggesting that the decision to follow medical advice and close the 
border - which was favored by women — was also instrumental in aiding the ALP's success at the election.

Table 4: Attitude to Border Closure

\begin{tabular}{|l|l|l|l|}
\hline & $\begin{array}{l}\text { Queensland } \\
\text { Electors }\end{array}$ & Gender \\
\hline & Oct 12-15,2020 & Men & Women \\
\hline & percent & percent & percent \\
\hline Yes, open the border & 47 & 51 & 43 \\
\hline No, don't open the border & 53 & 49 & 57 \\
\hline TOTAL & 100 & 100 & 100 \\
\hline
\end{tabular}

Source: Roy Morgan ${ }^{33}$

\section{Conclusion: Was the Key to Palaszcuk's Success 'Feminist Stewardship'?}

When women are represented in the highest positions of leadership, they are more likely to consider the gendered impact of their decisions, even those made in crisis. ${ }^{34}$ Female leaders in Norway and New Zealand held special briefings for children; talked about teachers, childcare workers, and aged care workers; and debated school closures from a perspective that included the rights of parents and teachers. In the Queensland example, Palaszczuk paid attention to social protections and welfare; was alert to domestic violence implications of lockdown; showed deference to expert medical advice by a legal transfer of power; and undertook personal, everyday forms of communication with the electorate. She favored closing the borders to prioritize physical health over economic impacts, despite considerable and very personal criticism from political opponents and those in her own party. Yet she was not the 'mothering' feminist protector of Jacinda Ardern. Instead, we conclude that rather than leaning into mothering archetypes during a crisis, she more strongly constituted having a feminist stewardship style of leadership - more feminist in aims if not deportment.

Even so, her feminist stewardship was not without critique. We know from feminist institutionalist literature, that when a crisis strikes, informal gendered rules-of-the-game do continue to dominate decisionmaking and discussion. ${ }^{35,36}$ Neither the Queensland election nor the state or national budgets gave any space or attention to gender-sensitive economic recovery policies. Indeed, both candidates spent most of the election period in high-visibility vests associated with the mining and construction sectors - more maledominated sectors in Queensland. A deeper sense of feminist approaches to economic recovery is not yet witnessed in the stewardship model. Authers and Charlesworth have noted that a "focus on crisis" often creates an "inattentiveness to persistent patterns of discrimination and violence." They argue that crisis "imbues some human rights violations with drama, making others recede drably into the background." 37 The next step for gendered leadership would be to see a focus on protecting the economic status of women through the use of political power. The stewardship approach during a pandemic perhaps offers a better foundation for that endeavor than that of a protector. Further exploring this is a needed focus for future research-particularly in the context of other female leaders who follow the same patterns of feminist stewardship, not mothering protectorship, during a crisis. 


\section{Notes}

${ }^{1}$ Dennis Tourish, "Introduction to the Special Issue: Why the Coronavirus Crisis Is Also a Crisis of Leadership," Leadership 16, no. 3 (June 2020).

${ }^{2}$ Carol Johnson and Blair Williams, "Gender and Political Leadership in a Time of COVID," Politics \& Gender 16 (2020).

${ }^{3}$ Johnson and Williams, "Gender and Political Leadership in a Time of COVID," 945.

${ }^{4}$ See further: Kayla Sergent and Alexander D. Stajkovic, "Women's Leadership Is Associated with Fewer Deaths During the COVID-19 Crisis: Quantitative and Qualitative Analyses of United States Governors," Journal of Applied Psychology 105, no. 8 (2020): 771-783.

${ }^{5}$ Thomas Schillemans, "Moving Beyond The Clash of Interests: On Stewardship Theory and the Relationships between Central Government Departments and Public Agencies," Public Management Review 15, no. 4 (May 2013).

${ }^{6}$ Johnson and Williams, "Gender and Political Leadership in a Time of COVID."

${ }^{7}$ Supriya Garikipati and Uma Khambhampati, "Leading the Fight against the Pandemic: Does Gender Really Matter?" Discussion Paper No. 2020-13. Centre for Economics and Policy Research, (2020).

${ }^{8}$ Garikipati and Khambhampati, "Leading the Fight against the Pandemic: Does Gender Really Matter?" (2020), 14.

${ }^{9}$ Ibid., "Leading the Fight against the Pandemic: Does Gender Really Matter?" (2020), 14.

${ }^{10}$ Queensland Health. "Covid-19 Update.” Accessed March 3, 2021.

${ }^{11}$ Alice H. Eagly, John M. MacEachranm Memorial Lecture Series. Sex Differences in Social Behavior: A Socialrole Interpretation, Lawrence Erlbaum Associates, Inc., 1987.

${ }^{12}$ Alice H. Eagly and Maureen Crowley, "Gender and Helping Behavior: A Meta-Analytic Review of the Social Psychological Literature," Psychological Bulletin 100, no. 3 (1986).

${ }^{13}$ Joseph C. Rost, Leadership in the 21st Century, (New York: Praeger, 1991).

${ }^{14}$ Thomas Schillemans, "Moving Beyond The Clash of Interests: On Stewardship Theory and the Relationships between Central Government Departments and Public Agencies," Public Management Review 15, no. 4 (May 2013): 544.

${ }^{15}$ Despite the progressive change in the cabinet, the Queensland parliament remained male dominant with 64 (68.8 percent) male members to 29 (31.2 percent) female members. This roughly 70-30, male-female split places Queensland's parliament on equal footing with the Australian parliament (30.5 percent woman) and the parliament of Germany (31.2 percent woman).

${ }^{16}$ Chris Salisbury, "A Tale of Two Parties: Contrasting Performances of Annastacia Palaszczuk's Labor and the Post-Newman LNP in Queensland," Queensland Review 25 no. 1 (2018): 51.

${ }^{17}$ Queensland Government, Public Health Act 2005, https://www.legislation.qld.gov.au/view/pdf/inforce/current/act-2005-048.

${ }^{18}$ Yasmin Kofman and Dana Rose Garfin, 'Home is not always a haven: the domestic violence crisis amid the COVID-19 pandemic', Psychological Trauma: Theory, Research, Practice and Policy 12 (S1), 199-201.

${ }^{19}$ Cinzia Meraviglia, 'The gendered division of unpaid labour during the COVID-19 crisis: did anything change? Evidence from Italy', International Journal of Sociology 51 (1), 64-75.

${ }^{20}$ Clare Wenham, Julia Smith, and Rosemary Morgan, 'COVID-19: the gendered impacts of the outbreak', The Lancet 395 (10227), 846-848 (March 14, 2020).

${ }^{21}$ UN Women, "The Shadow Pandemic: Violence against Women During COVID-19" (2020), https://www.unwomen.org/en/news/in-focus/in-focus-gender-equality-in-covid-19-response/violenceagainst-women-during-covid-19

${ }^{22}$ ILO, "Fallout of Covid-19 Working moms are being squeezed out of the labour market" November 27, 2020, https://ilostat.ilo.org/fallout-of-covid-19-working-moms-are-being-squeezed-out-of-the-labourforce/\#: :text=According\%20to\%20data\%20from\%2055,women's\%20proportional $\% 201$ oss $\% 20$ is $\% 20$ high er.

${ }^{23}$ Mathieu Boniol, Michelle McIsaac, Lihui Xu, Tana Wujili, Khassoum Diallo, and Jim Campbell, "Gender Equity in the Health Workforce: Analysis of 104 Countries," Working Paper 1 (March 2019).

${ }^{24}$ Naaman Zhou, "Female Enrolment at Australian Universities Dropped by 86,000 in 2020 as 'Pink Recession' Hit," The Guardian, November 11, 2020.

${ }^{25}$ Australian Bureau of Statistics. Accessed February 20, 2021.

${ }^{26}$ Ibid. Accessed February 21, 2021. 
${ }^{27}$ Australian Government, "DSS Payment Demographic Data," February 25, 2021, https://data.gov.au/dataset/dsdga-cff2ae8a-55e4-47db-a66d-e177fe0ac6a0/details?q=DSS.

${ }^{28}$ Australian Tax Office, Administrative data; ABS Labour Force, Australia, Detailed, Quarterly, May 2020 (Cat. No. 6291.0.55.003).

${ }^{29}$ Frank P. Larkins, “Australian University Staffing Trends over the Decade 2008-2017,” (2018): 1-7.

${ }^{30}$ Lester Gunnion and Monali Samaddar, "Why the COVID-19 Recession has Disproportionately Affected Women," Deloitte, (January 29, 2021), https://www2.deloitte.com/za/en/insights/economy/spotlight/economics-insights-analysis-01-2021.html.

${ }^{31}$ Parliament of Australia, "COVID-19: Labour Market Impacts on Key Demographic Groups, Industries and Regions," October 23, 2020, https://www.aph.gov.au/About_Parliament/Parliamentary Departments/Parliamentary Library/pubs/rp/rp2 021/COVID-19-Stat_Snapshot.

${ }^{32}$ Roy Morgan, "ALP Government Leads with a Slim Majority in Queensland; Small Majority of Queenslanders Don't Want NSW Border Open Now,” October 21, 2020, https://www.roymorgan.com/findings/8548-roymorgan-queensland-election-voting-intention-nsw-border-october-2020-202010201001.

${ }^{33}$ Roy Morgan, "ALP Government Leads with a Slim Majority in Queensland; Small Majority of Queenslanders Don't Want NSW Border Open Now," October 21, 2020, https://www.roymorgan.com/findings/8548-roymorgan-queensland-election-voting-intention-nsw-border-october-2020-202010201001.

${ }^{34}$ Elise Stephenson and Susan Harris Rimmer, "COVID-19 responses: why feminist leadership matters in a crisis", The Lowy Institute - The Interpreter, (31 March 2020), https://www.lowyinstitute.org/the-interpreter/covid19-responses-why-feminist-leadership-matters-crisis

${ }^{35}$ Fiona Mackay, Meryl Kenny, and Louise Chappell, "New Institutionalism Through a Gender Lens: Towards a Feminist Institutionalism?", International Political Science Review 31(5), 573-588.

${ }^{36}$ Vivien Lowndes, "How Are Things Done Around Here? Uncovering Institutional Rules and their Gendered Effects," Politics \& Gender 10, no. 4 (2014): 686.

${ }^{37}$ Benjamin Authers and Hilary Charlesworth, "The Crisis and the Quotidian in International Human Rights Law," Netherlands Yearbook of International Law 44, 19 (2012): 19.

\section{Notes}

Australian Bureau of Statistics. Accessed February 20, 2021, https://www.abs.gov.au/statistics/labour/employment-and-unemployment/labour-forceaustralia/latest-release.

Australian Government. "DSS Payment Demographic Data.” February 25, 2021, https://data.gov.au/dataset/ds-dga-cff2ae8a-55e4-47db-a66d-e177fe0ac6a0/details?q=DSS.

Australian Tax Office. Administrative data; ABS Labour Force, Australia, Detailed, Quarterly, May 2020 (Cat. No. 6291.0.55.003).

Authers, Benjamin and Hilary Charlesworth. "The Crisis and the Quotidian in International Human Rights Law." Netherlands Yearbook of International Law 44, 19 (2012): 19-30.

Boniol, Mathieu, Michelle McIsaac, Lihui Xu, Tana Wujili, Khassoum Diallo, and Jim Campbell. "Gender Equity in the Health Workforce: Analysis of 104 Countries." Working Paper 1 (March 2019). https://apps.who.int/iris/bitstream/handle/10665/311314/WHO-HIS-HWF-Gender-WP12019.1-eng.pdf. 
Champoux-Paillé, Louise and Anne-Marie Croteau. "Why Women Leaders Are Excelling During the Coronavirus Pandemic." The Conversation. 2020. https://theconversation.com/why-womenleaders-areexcelling-during-the-coronavirus-pandemic-138098 (accessed 20 April 2020).

Chappell, Louise and Fiona Mackay. "What's in a Name? Mapping the Terrain of Informal Institutions and Gender Politics." In G Waylen (Ed.), Gender and Informal Institutions: Feminist Institutionalist Perspectives. Lanham, MD: Rowman \& Littlefield International, 2017. 23-44.

Eagly, Alice H. John M. MacEachranm Memorial Lecture Series. Sex Differences in Social Behavior: A Social-role Interpretation. Lawrence Erlbaum Associates, Inc., 1987.

Eagly, Alice H. and Maureen Crowley. "Gender and Helping Behavior: A Meta-Analytic Review of the Social Psychological Literature." Psychological Bulletin 100, no. 3 (1986): 283-308.

Eagly, Alice H. and B.T. Johnson (1990). "Gender and Leadership Style: A Meta-Analysis." CHIP Documents 11. https://opencommons.uconn.edu/chip_docs/11.

Garikipati, Supriya and Uma Khambhampati. "Leading the Fight against the Pandemic: Does Gender Really Matter?" Discussion Paper No. 2020-13. Centre for Economics and Policy Research. (2020). doi:10.2139/ssrn.3617953.

Gunnion, Lester and Monali Samaddar. "Why the COVID-19 Recession has Disproportionately Affected Women," Deloitte. January 29, 2021. https://www2.deloitte.com/za/en/insights/economy/spotlight/economics-insights-analysis-012021.html.

Henley, Jon and Eleanor Ainge Roy. "Are female leaders more successful at managing the coronavirus crisis?" Guardian, April 25, 2020. https://www.theguardian.com/world/2020/apr/25/why-dofemale-leaders-seem-to-be-more-successful-at-managing-the-coronavirus-crisis.

Interparliamentary Union. "Women in Politics.” Accessed April 20, 2020. https://www.ipu.org/resources/publications/infographics/2020-03/women-in-politics-2020.

Johnson, Carol and Blair Williams. "Gender and Political Leadership in a Time of COVID." Politics \& Gender 16 (2020): 943-950.

Larkins, Frank P. “Australian University Staffing Trends over the Decade 2008-2017.” (2018): 1-7. https://melbournecshe.unimelb.edu.au/_data/assets/pdf_file/0005/2939702/F_Larkins_Australian-UniversitiesStaffing-Trends-over-the-Decade-2008-to-2017.pdf.

Lewis, Helen. "The Pandemic has Revealed the Weakness of Strongmen." The Atlantic. May 6, 2020. https://www.theatlantic.com/international/archive/2020/05/new-zealand-germany-womenleadershipstrongmen-coronavirus/611161/

Lowndes, Vivien. "How Are Things Done Around Here? Uncovering Institutional Rules and their Gendered Effects." Politics \& Gender 10, no. 4 (2014): 685-91.

McLean, Victoria. "Coronavirus Is Showing Yet Again Why the World Needs More Strong Female Decision-Makers.” April 12, 2020. https://www.euronews.com/2020/05/12/coronavirus-showingyet-again-why-the-world-needsmore-strong-female-decision-makers-view.

Nelson, Julia A. "Are Women Really More Risk-Averse than Men? A Re-Analysis of the Literature Using Expanded Methods.” Journal of Economic Surveys 29, no. 3 (2015): 566-85.

Parliament of Australia. "COVID-19: Labour Market Impacts on Key Demographic Groups, Industries and Regions." October 23, 2020, https://www.aph.gov.au/About Parliament/Parliamentary Departments/Parliamentary Library/p ubs/rp/rp2021/COVID-19-Stat Snapshot.

Queensland Health. "Covid-19 Update.” Accessed March 3, 2021, https://www.qld.gov.au/health/conditions/health-alerts/coronavirus-covid-19.

Rost, Joseph C. Leadership in the 21st Century. New York: Praeger, 1991.

Roy Morgan. "ALP Government Leads with a Slim Majority in Queensland; Small Majority of Queenslanders Don’t Want NSW Border Open Now.” October 21, 2020, 
https://www.roymorgan.com/findings/8548-roy-morgan-queensland-election-voting-intentionnsw-border-october-2020-202010201001.

Salisbury, Chris. "A Tale of Two Parties: Contrasting Performances of Annastacia Palaszczuk's Labor and the Post-Newman LNP in Queensland." Queensland Review 25 no. 1 (2018): 50-61. doi:10.1017/qre.2018.6.

Sergent, Kayla, and Alexander D. Stajkovic. "Women's Leadership Is Associated with Fewer Deaths During the COVID-19 Crisis: Quantitative and Qualitative Analyses of United States Governors." Journal of Applied Psychology 105, no. 8 (2020): 771-783.

Schillemans, Thomas. "Moving Beyond The Clash of Interests: On Stewardship Theory and the Relationships between Central Government Departments and Public Agencies." Public Management Review 15, no. 4 (May 2013): 541-62. doi:10.1080/14719037.2012.691008.

Taub, Amanda. "Why Are Women-Led Nations Doing Better With Covid-19?" New York Times, May 15, 2020. https://www.nytimes.com/2020/05/15/world/coronavirus-women-leaders.html.

Tourish, Dennis. "Introduction to the Special Issue: Why the Coronavirus Crisis Is Also a Crisis of Leadership." Leadership 16, no. 3 (June 2020): 261-72. https://doi.org/10.1177/1742715020929242.

Wittenberg-Cox, Avivah. "What Do Countries with Best Coronavirus Responses Have in Common? Women Leaders." Forbes. April 13, 2020.

https://www.forbes.com/sites/avivahwittenbergcox/2020/04/13/what-do-countries-with-the-bestcoronavirus-reponses-have-in-common-women-leaders/?sh=3ed0c $2 \mathrm{bc} 3 \mathrm{dec}$.

Zhou, Naaman. "Female Enrolment at Australian Universities Dropped by 86,000 in 2020 as 'Pink Recession' Hit." The Guardian. November 11, 2020. https://www.theguardian.com/australianews/2020/nov/12/female-enrolment-at-australian-universities-dropped-by-86000-in-2020-aspink-recession-hit\#: :text=3per cent20monthsper cent20old-,Femaleper cent20enrolmentper cent20atper cent20Australianper cent20universitiesper cent20droppedper cent20by,2020per cent20asper cent20'pinkper cent20recession'per cent20hit\&text=Newlyper cent20releasedper cent20dataper cent 20 fromper cent 20 the, inper cent 20 theper cent 20 numberper cent 20 ofper cent20men. 